\title{
Research on User Experience Index Weighting Method Based on Grey Relation Analysis \\ - With Intra-City Freight Internet Products as Example
}

\author{
Yizi Chen ${ }^{\mathrm{a}, 1}$, Qiang $\mathrm{Yu}^{\mathrm{a}}$ \\ ${ }^{a}$ Design Innovation Center, China Academy of Art, Hangzhou, China, 310024
}

\begin{abstract}
Intra-city freight Internet products, combined with the index system thereof, are selected as the research object in this study. We have brought in Grey Relation Analysis to study the correlation between index layers, proposing a new index weighting method for user experience measurement to explore the iteration of two versions of Didi Freight. This paper is about to show its effectiveness and discusses its future scalability in light of the preliminary verification results.
\end{abstract}

Keywords. Index Weighting, User Experience Measurement, Grey Relation Analysis, Intra-city Freight

\section{Introduction}

Good user experience is the prerequisite for internet products to better meet the use requirements and emotional needs of their users and prolong the life cycle [1]. As a set of scientific and effective quantitative evaluation standards, user experience measurement can appraise internet products in a three-dimensional way and feed back quantitative user experience results [2]. Through index weighting on the user experience, the demand dimension of internet products in this regard can be much clearer, with more accurate user experience measurement leading to optimized results.

Traditional user experience index weighting methods entail a tidal wave of data and typical distribution, flawed in computation burden and frequent correlation errors resulting in distortion of facts. Grey Relation Analysis (GRA) is different from Regression Analysis, Analysis of Variance, Principal Components Analysis and other traditional mathematical statistics methods[3].It overcomes these strict requirements, exploring the numerical association between factors of a grey system to judge their correlation according to the consistency analysis of the development trend among various factors. The core idea is to compare the geometrical similarity between sequences. The higher the consistency is, the higher the grey correlation will be. Otherwise, it will go lower[4]. GRA brings a new perspective to the research of user experience index weighting, which has great significance.

\section{Method}

Based on the typical characteristics of intra-city freight and its complex online and offline application scenes, this paper selects intra-city freight Internet products as the object and

\footnotetext{
${ }^{1}$ Corresponding author: Yizi Chen; Postal address: Design Innovation Center, China Academy of Art, Hangzhou, China, 310024 ; Email address: chenyz-1@163.com
} 
proposes a new index weighting method for user experience measurement in this regard. We will testify the feasibility of the method, working to optimize the user experience. The following sections are more details of experimental methods and contents.

\subsection{Preparation}

Experimental preparation mainly includes the following two parts.

\subsubsection{Design a user experience questionnaire}

As for the characteristics of intra-city freight, we refer to research on measurement of intra-city freight Internet products in terms of user-friendliness and customer satisfaction. Finally, we construct the index system (as shown in the following figure) for user experience measurement of intra-city freight Internet products, concerning their basic features, service diversity, cost complexity, and security.

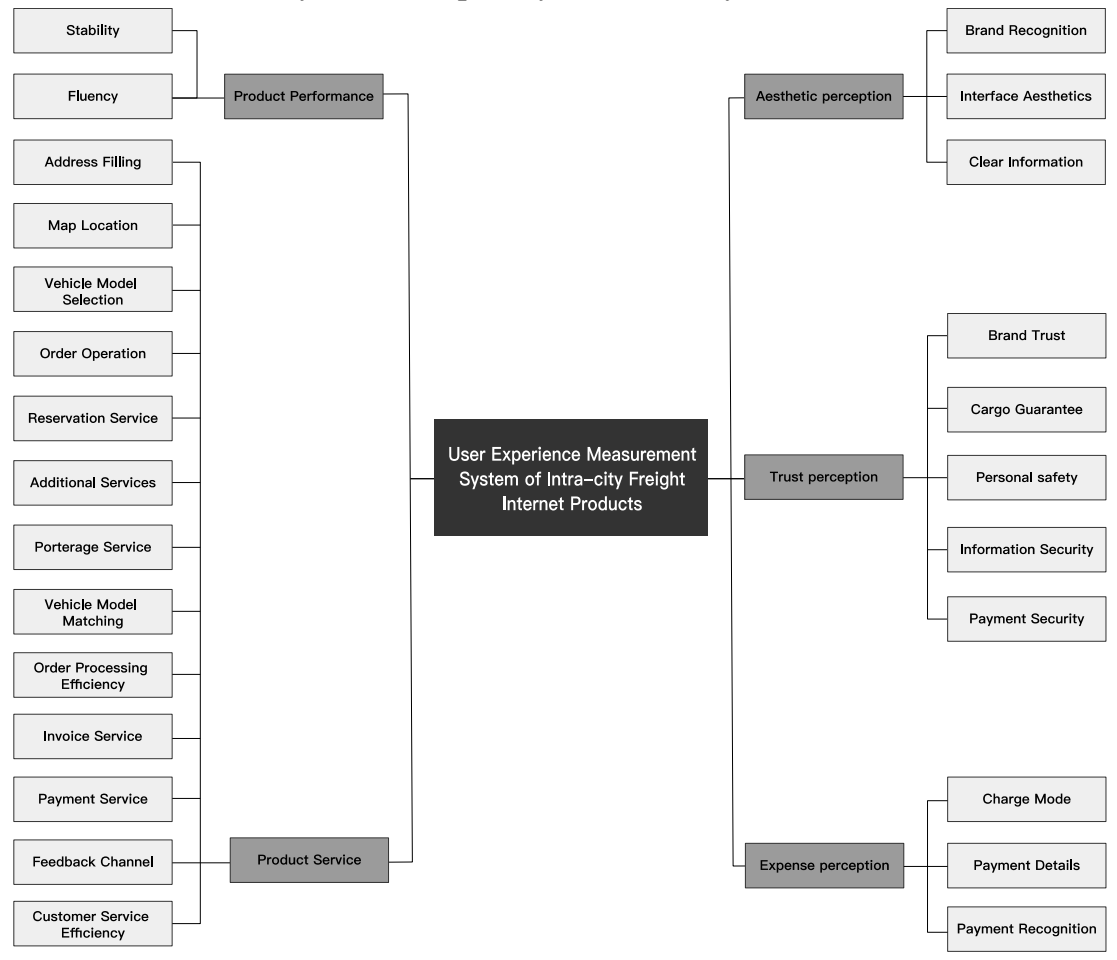

Figure 1. Index system for user experience measurement of intra-city freight Internet products.

On this basis, a questionnaire was designed taking into account the importance of all primary indexes and their subordinate secondary indexes in the index system to the product experience. The questionnaire consists of two parts: (1)the basic information of the respondents, with 3 questions; and (2)the importance rating of the primary and secondary indexes of intra-city freight internet products experience, with 31 questions designed by 7-point Likert scale. The questionnaire was also adopted in the subsequent user experience evaluation experiments and analyses. 


\subsubsection{Use GRA to Establish Index Weighting Method}

In the measurement of intra-city freight internet products, on account of the constructed user experience index system of "product experience rating - primary index - secondary index", this paper analyzed and weighted correlations between index levels through gray correlation analysis. After collecting the importance ratings of primary and secondary indexes from typical users through the scale, it took the data of primary indexes as reference sequences and that of secondary indexes as comparative sequences, with the correlation between secondary and primary indexes calculated by gray correlation analysis. The higher the correlation, the greater the influence of the secondary index on the primary index[5]. The weight of the secondary index was obtained by calculating the ratio of correlation rating to the overall correlation rating, as shown in the figure below:

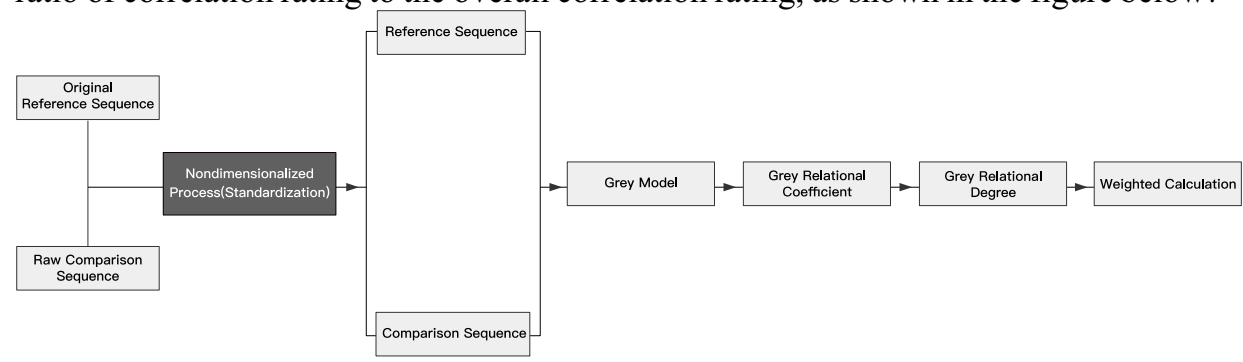

Figure 2. Flow of Gray Correlation Analysis for User Experience Measurement.

Specific steps are as follows:

- Firstly, determine reference sequences and comparative sequences.

The reference sequences refer to those which can map system behaviors, that is, indirect indicators, while comparative sequences are those affecting the system behaviors[6].. With first-level indicators as the reference sequences and their subordinate second-level indicators as the comparative sequences, this is a reference sequence of the nth scored object:

$$
X_{o \text { Reference Sequence }}=\left\{X_{0}(k),(k=1,2,3 \ldots n)\right\} .
$$

And the comparative sequence was as follows:

$$
\begin{aligned}
& X_{i \text { Comparison Sequence }}=\left\{X_{i}(k),(k=1,2,3 \ldots n)\right\}, \\
& \mathrm{i}=\left(1_{\text {Comparison Sequence } 1}, 2_{\text {Comparison Sequence2 }}, \ldots m_{\text {Comparison Sequence } m}\right) \text {, } \\
& X_{i}(k) \text { denotes the rating of the } \mathrm{k}^{\text {th }} \text { evaluation object on the } i^{\text {th }} \text { index, and } \mathrm{m} \text { is }
\end{aligned}
$$

- Secondly, nondimensionalization (standardization) of reference sequences $X_{o}$ and comparative sequences $X_{i}$.

In the case of a positive correlation between general factors and the system, three calculation methods based on initialization, averaging, and interval values respectively can be used[7]. In this paper, we adopt initialization, where all data of the same sequence are divided by the first data to obtain a new sequence.

- Thirdly, establish a grey model. 
Used the formula in step (i) and the method in step (ii) to obtain the evaluation value $X_{i}(k)$ of the kth user for the $i^{\text {th }}$ dimension and generate the gray model as follows:

Table 1. Establishment of grey models.

\begin{tabular}{|c|c|c|c|c|c|c|}
\hline & & User 1 & User 2 & User 3 & $\ldots$ & User $n$ \\
\hline $\begin{array}{l}\text { Reference } \\
\text { Sequence }\end{array}$ & $\begin{array}{l}\text { Primary } \\
\text { index }\left(\mathrm{X}_{0}\right)\end{array}$ & $\mathrm{X}_{0}(1)$ & $\mathrm{X}_{0}(2)$ & $\mathrm{X}_{0}(3)$ & $\cdots$ & $\mathrm{X}_{0}(\mathrm{n})$ \\
\hline \multirow{3}{*}{$\begin{array}{l}\text { Comparative } \\
\text { Sequence }\end{array}$} & $\begin{array}{l}\text { Secondary } \\
\text { index } 1\left(X_{1}\right)\end{array}$ & $X_{1}(1)$ & $X_{1}(2)$ & $X_{1}(3)$ & $\ldots$ & $\mathrm{X}_{1}(\mathrm{n})$ \\
\hline & $\begin{array}{l}\text { Secondary } \\
\text { index } 2\left(\mathrm{X}_{2}\right)\end{array}$ & $\mathrm{X}_{2}(1)$ & $\mathrm{X}_{2}(2)$ & $\mathrm{X}_{2}(3)$ & $\cdots$ & $\mathrm{X}_{2}(\mathrm{n})$ \\
\hline & $\begin{array}{l}\text { Secondary } \\
\text { index } 3\left(X_{3}\right)\end{array}$ & $\mathrm{X}_{3}(1)$ & $\mathrm{X}_{3}(2)$ & $\mathrm{X}_{3}(3)$ & $\ldots$ & $X_{3}(4)$ \\
\hline
\end{tabular}

- Fourth, Calculate the grey relational coefficient.

Grey correlation coefficients indicate the correlation between each comparative sequence and the corresponding reference sequence at each point. The adopted formula is as follows:

$$
\xi_{i}(k)=\frac{\min _{i} \min _{k}\left|X_{0}(k)-X_{i}(k)\right|+\mathrm{p} \max _{i} \max _{k}\left|X_{0}(k)-X_{i}(k)\right|}{\left|X_{0}(k)-X_{i}(k)\right|+\mathrm{p} \max _{i} \max _{k}\left|X_{0}(k)-X_{i}(k)\right|}
$$

Where, $\min _{i} \min _{k}\left|X_{0}(k)-X_{i}(k)\right|$ is the absolute value of the minimum difference between the two poles, $\max _{i} \max _{k}\left|X_{0}(k)-X_{i}(k)\right|$ is the absolute value of the maximum difference between the two poles, and $\mathrm{p}$ is the identification coefficient, ranging from 0 to 1 , usually 0.5 .

- Fifth, calculated the gray correlation.

In most cases, gray correlation is the mean of gray correlation coefficients. The importance of the secondary index to the primary index can be revealed by ranking them by correlation. The correlation is denoted as $r_{i}$, and the expression is as follows:

$$
r_{i}=\frac{1}{n} \sum_{k=1}^{n} r_{0 i}(k)
$$

- Sixth,Weighed indexes.

The secondary indexes were weighed by calculating the proportion of their correlation in the total correlation according to the steps above. The primary indexes were weighted by referring to the proportion of mean importance rating in the total mean. 


\subsection{Experiment Process}

Upon appointment with the respondents, there was a one-on-one user experience evaluation experiment, which took about $40 \mathrm{~min}$ in total. The experiment process consists of the following four parts:

\section{- Questionnaire design and distribution.}

The questionnaire survey targeted 10 intra-city freight internet experts who have been in the user experience industry for more than 10 years, and 10 in-depth users from B- and C-end of mainstream intra-city freight application areas, such as building materials market, clothing and fabric market, decoration market, and flower and bird market, for user experience evaluation experiments.

\section{- Descriptive statistics.}

A total of 20 questionnaires were distributed offline, of which 20 were valid. Respondents were equally gender split, with $55 \%$ male and $45 \%$ female. The experts were all aged between 31 and 40, and the respondents were all between 41 and 50, which matched the background profile of the two groups.

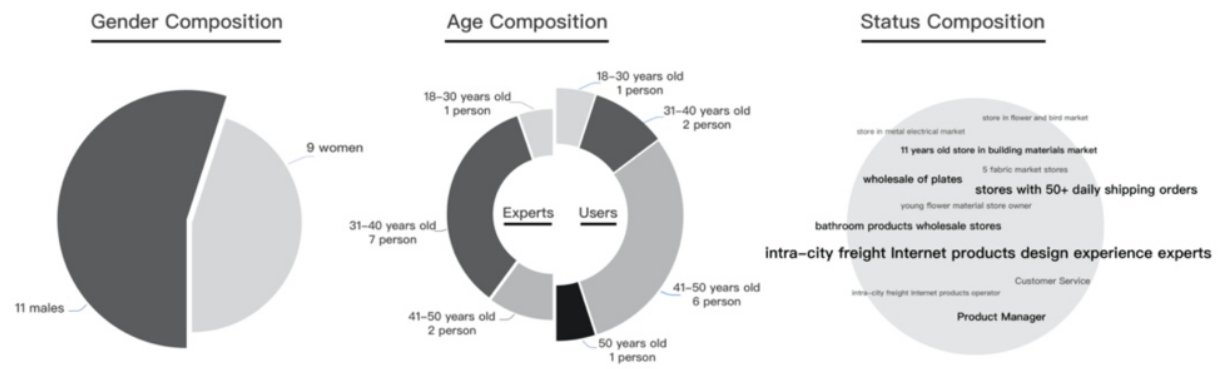

Figure 3. Descriptive Statistics of the Results of Measurement Index Importance Questionnaire.

\section{- Reliability and validity tests.}

This paper uses Cronbach's alpha to test the reliability of the questionnaire. A reliability coefficient greater than 0.8 indicates favorable reliability[8]. After calculating by SPSS, the Cronbach $\alpha$ of the questionnaire was 0.891 , so it passed the reliability test.

Table 2. Reliability Test of Measurement Index Importance Questionnaire.

\begin{tabular}{c|c}
\hline Cronbachs alpha & Number of measured terms \\
\hline 0.891 & 31 \\
\hline
\end{tabular}

The validity test was conducted by triangulation[9]. The questionnaire was sent to 20 respondents, with 10 intra-city freight internet experts rating the importance of indexes from the perspectives of industry research, product strategy, and experience design; and 10 in-depth intra-city freight users rating from the perspective of product developers and users, thus ensuring the validity of the study. 


\section{- Semi-structured interview.}

After the respondents completed the questionnaire, semi-structured interviews were conducted to see if those users were satisfied[10]. More questions were raised according to their answers to the questionnaire to further explore the factors of user experience. The results of the questionnaire were compared to ensure the comprehensiveness of the study.

\section{Results and discussion}

We have recorded the experiment at any link, besides photographing manuscripts drawn by participants. The specific content of the experimental analysis mainly includes two stages, as shown in Table 3:

Table 3. Two main contents of experimental analysis.

\begin{tabular}{|c|c|c|}
\hline & Stage & Summary of results \\
\hline \multirow{4}{*}{1} & \multirow{4}{*}{$\begin{array}{l}\text { Index weighting for user } \\
\text { experience measurement } \\
\text { of intra-city freight } \\
\text { Internet products }\end{array}$} & $\begin{array}{l}\text { (1) Through the experimental analysis, the grey modeling method } \\
\text { is adopted to establish grey models in line with five dimensions } \\
\text { (including product performance, product service, aesthetic } \\
\text { perception, trust perception, and cost perception) of user } \\
\text { experience measurement in intra-city freight. Exemplify the grey } \\
\text { model in the case of "trust perception". }\end{array}$ \\
\hline & & $\begin{array}{l}\text { (2) Then, substitute the five dimensions and their second-level } \\
\text { indexes into the formulas of the grey relational coefficient } \xi_{i}(k) \\
\text { and grey relational degree ri to obtain corresponding results. } \\
\text { Exemplify the calculation process in the case of "trust perception". }\end{array}$ \\
\hline & & $\begin{array}{l}\text { (3) Conduct weighting on each second-level index under the same } \\
\text { dimension pursuant to the ratio of the corresponding grey relational } \\
\text { degree to the total correlation degree. Exemplify the calculation } \\
\text { process in the case of "trust perception". }\end{array}$ \\
\hline & & $\begin{array}{l}\text { (4) At last, carry out weighting on each first-level index, pursuant } \\
\text { to the ratio of its score on the importance to the total score to obtain } \\
\text { the weighted indexes for user experience measurement of the intra- } \\
\text { city freight Internet products. By doing so, a user experience } \\
\text { measurement model in this regard can be finally constructed. }\end{array}$ \\
\hline \multirow{3}{*}{2} & \multirow{3}{*}{$\begin{array}{l}\text { Verification of user } \\
\text { experience measurement } \\
\text { for intra-city freight } \\
\text { Internet products }\end{array}$} & $\begin{array}{l}\text { (1) Through user experience measurement on DIDI Freight v1.0, } \\
\text { relevant baselines are established, shedding light on the } \\
\text { optimization of products and justifying suggestions on iteration. }\end{array}$ \\
\hline & & $\begin{array}{l}\text { (2) Then, after another experience measurement on DIDI Freight } \\
\text { v2.0, the actual optimization and results of products during this } \\
\text { period should be concerned for analysis. }\end{array}$ \\
\hline & & $\begin{array}{l}\text { (3) The comparison of these two versions has justified the positive } \\
\text { role of index weighting on improving the accuracy of user } \\
\text { experience measurement and leading future optimization in this } \\
\text { regard. }\end{array}$ \\
\hline
\end{tabular}

\subsection{Index weighting for user experience measurement}

- According to the data acquired from the questionnaire, five first-level indexes were taken as the reference sequence, while their corresponding second-level 
indexes were taken as the comparative sequence. Exemplify the grey relational degree and weighted calculation on the grounds of the first-level index - trust perception, as well as its second-level indexes, including brand credit, guarantee on goods, personal safety, information security, and payment security. Use the grey modeling method described above to build a grey model based on trust perception as follows:

Table 4. Grey model in the case of trust perception.

\begin{tabular}{|c|c|c|c|c|c|c|}
\hline \multirow{2}{*}{$\begin{array}{l}\text { Subject } \\
\text { Number }\end{array}$} & \multirow{2}{*}{$\begin{array}{l}\begin{array}{l}\text { Reference } \\
\text { sequence }\end{array} \\
\text { Trust } \\
\text { perception }\end{array}$} & \multicolumn{5}{|c|}{ Comparative sequence } \\
\hline & & $\begin{array}{l}\text { Brand } \\
\text { credit }\end{array}$ & $\begin{array}{l}\text { Guarantee } \\
\text { on goods }\end{array}$ & $\begin{array}{l}\text { Personal } \\
\text { safety }\end{array}$ & $\begin{array}{l}\text { Information } \\
\text { security }\end{array}$ & $\begin{array}{l}\text { Payment } \\
\text { security }\end{array}$ \\
\hline 01 & 1.000 & 1.000 & 1.000 & 1.000 & 1.000 & 1.000 \\
\hline 02 & 1.000 & 1.500 & 1.167 & 0.857 & 0.833 & 1.200 \\
\hline 03 & 1.167 & 1.500 & 1.167 & 1.000 & 0.833 & 1.400 \\
\hline 04 & 0.833 & 1.500 & 1.167 & 1.000 & 1.000 & 1.400 \\
\hline 05 & 1.167 & 1.500 & 1.167 & 1.000 & 1.000 & 1.400 \\
\hline 06 & 1.000 & 1.250 & 1.000 & 1.000 & 1.167 & 1.400 \\
\hline 07 & 1.000 & 1.500 & 1.000 & 1.000 & 0.833 & 1.400 \\
\hline 08 & 0.833 & 1.750 & 1.167 & 1.000 & 0.833 & 0.800 \\
\hline 09 & 1.000 & 1.500 & 1.000 & 0.857 & 1.000 & 1.200 \\
\hline 10 & 1.000 & 1.500 & 1.167 & 1.000 & 0.667 & 1.200 \\
\hline 11 & 0.833 & 1.750 & 1.167 & 1.000 & 0.833 & 0.800 \\
\hline 12 & 1.000 & 1.500 & 1.000 & 1.000 & 1.000 & 1.200 \\
\hline 13 & 1.167 & 1.500 & 1.167 & 1.000 & 1.167 & 1.400 \\
\hline 14 & 1.000 & 1.250 & 1.000 & 0.857 & 1.000 & 1.200 \\
\hline 15 & 1.000 & 1.500 & 1.167 & 1.000 & 1.000 & 1.400 \\
\hline 16 & 1.000 & 1.250 & 1.000 & 1.000 & 1.000 & 1.400 \\
\hline 17 & 0.833 & 1.500 & 1.167 & 0.857 & 1.167 & 1.400 \\
\hline 18 & 1.000 & 1.500 & 1.000 & 1.000 & 0.833 & 1.400 \\
\hline 19 & 1.000 & 1.000 & 1.000 & 1.000 & 1.000 & 1.000 \\
\hline 20 & 1.000 & 1.500 & 1.167 & 1.000 & 0.667 & 1.200 \\
\hline
\end{tabular}

- Respectively figure out the grey relational coefficient $\xi_{i}(k)$ and the grey relational degree ri according to their formulas as follows:

Table 5. Relational coefficient and relational degree between sequences sorted by trust perception.

\begin{tabular}{l|l|l|l|l|l}
\hline \multirow{2}{*}{$\begin{array}{l}\text { Subject } \\
\text { Number }\end{array}$} & $\begin{array}{l}\text { Brand } \\
\text { credit }\end{array}$ & $\begin{array}{l}\text { Guarantee on } \\
\text { goods }\end{array}$ & $\begin{array}{l}\text { Personal } \\
\text { safety }\end{array}$ & $\begin{array}{l}\text { Information } \\
\text { security }\end{array}$ & $\begin{array}{l}\text { Payment } \\
\text { security }\end{array}$ \\
\cline { 2 - 5 } 01 & \multicolumn{5}{|c}{ Grey relational coefficient } \\
02 & 1.000 & 1.000 & 1.000 & 1.000 & 1.000 \\
03 & 1.500 & 1.167 & 0.857 & 0.833 & 1.200 \\
04 & 1.500 & 1.167 & 1.000 & 0.833 & 1.400 \\
05 & 1.500 & 1.167 & 1.000 & 1.000 & 1.400 \\
06 & 1.500 & 1.167 & 1.000 & 1.000 & 1.400 \\
\cline { 2 - 5 } & 1.250 & 1.000 & 1.000 & 1.167 & 1.400 \\
\hline
\end{tabular}




\begin{tabular}{l|lllll}
\hline 07 & 1.500 & 1.000 & 1.000 & 0.833 & 1.400 \\
08 & 1.750 & 1.167 & 1.000 & 0.833 & 0.800 \\
09 & 1.500 & 1.000 & 0.857 & 1.000 & 1.200 \\
10 & 1.500 & 1.167 & 1.000 & 0.667 & 1.200 \\
11 & 1.750 & 1.167 & 1.000 & 0.833 & 0.800 \\
12 & 1.500 & 1.000 & 1.000 & 1.000 & 1.200 \\
13 & 1.500 & 1.167 & 1.000 & 1.167 & 1.400 \\
14 & 1.250 & 1.000 & 0.857 & 1.000 & 1.200 \\
15 & 1.500 & 1.167 & 1.000 & 1.000 & 1.400 \\
16 & 1.250 & 1.000 & 1.000 & 1.000 & 1.400 \\
17 & 1.500 & 1.167 & 0.857 & 1.167 & 1.400 \\
18 & 1.500 & 1.000 & 1.000 & 0.833 & 1.400 \\
19 & 1.000 & 1.000 & 1.000 & 1.000 & 1.000 \\
20 & 1.500 & 1.167 & 1.000 & 0.667 & 1.200 \\
\cline { 2 - 6 } & & & Grey relational degree & \\
\cline { 2 - 6 } & 0.550 & 0.863 & 0.882 & 0.836 & 0.680 \\
\hline
\end{tabular}

- Calculate the weights of the five second-level indexes sorted by the trust perception in light of grey relational degree as follows:

Table 6. Weighted second-level indexes in the case of trust perception.

\begin{tabular}{ccccc}
\hline \multicolumn{4}{c}{ Index weight } \\
\hline Brand credit & Guarantee on & Personal safety & Information & Payment security \\
\hline 0.144 & 0.226 & 0.232 & 0.219 & 0.179
\end{tabular}

- Perform calculation on the other four first-level indexes (namely, product performance, product service, aesthetic perception, and cost perception) in the same way to obtain the final weighting results. Conduct weighting on each firstlevel index pursuant to the ratio of its average score on the importance to the total average to finally obtain the weighted indexes for user experience measurement of the intra-city freight Internet products. By doing so, a user experience measurement model in this regard can be finally constructed.

Table 7. User experience measurement model of intra-city freight Internet products.

\begin{tabular}{|c|c|c|c|c|c|c|}
\hline \multicolumn{2}{|l|}{$\begin{array}{l}\text { Measurement } \\
\text { Target }\end{array}$} & $\begin{array}{l}\text { First-level } \\
\text { Index }\end{array}$ & $\begin{array}{l}\text { First-level } \\
\text { index /total } \\
\text { target } \\
\text { weight }\end{array}$ & $\begin{array}{l}\text { Second-level } \\
\text { index }\end{array}$ & $\begin{array}{l}\text { Second-level } \\
\text { index / } \\
\text { First-level } \\
\text { index }\end{array}$ & $\begin{array}{l}\text { Second-level } \\
\text { index /total } \\
\text { target } \\
\text { weight }\end{array}$ \\
\hline \multirow{5}{*}{$\begin{array}{l}\text { User } \\
\text { Experience } \\
\text { Measurement } \\
\text { for Intra-city } \\
\text { Freight } \\
\text { Internet } \\
\text { Products }\end{array}$} & \multirow{5}{*}{1} & \multirow{2}{*}{$\begin{array}{l}\text { Product } \\
\text { performance }\end{array}$} & \multirow{2}{*}{0.194} & Stability & 0.583 & 0.113 \\
\hline & & & & Fluency & 0.417 & 0.081 \\
\hline & & \multirow{3}{*}{$\begin{array}{l}\text { Product } \\
\text { service }\end{array}$} & \multirow{3}{*}{0.204} & Address filling & 0.072 & 0.015 \\
\hline & & & & Positioning map & 0.061 & 0.012 \\
\hline & & & & Vehicle type & 0.091 & 0.019 \\
\hline
\end{tabular}




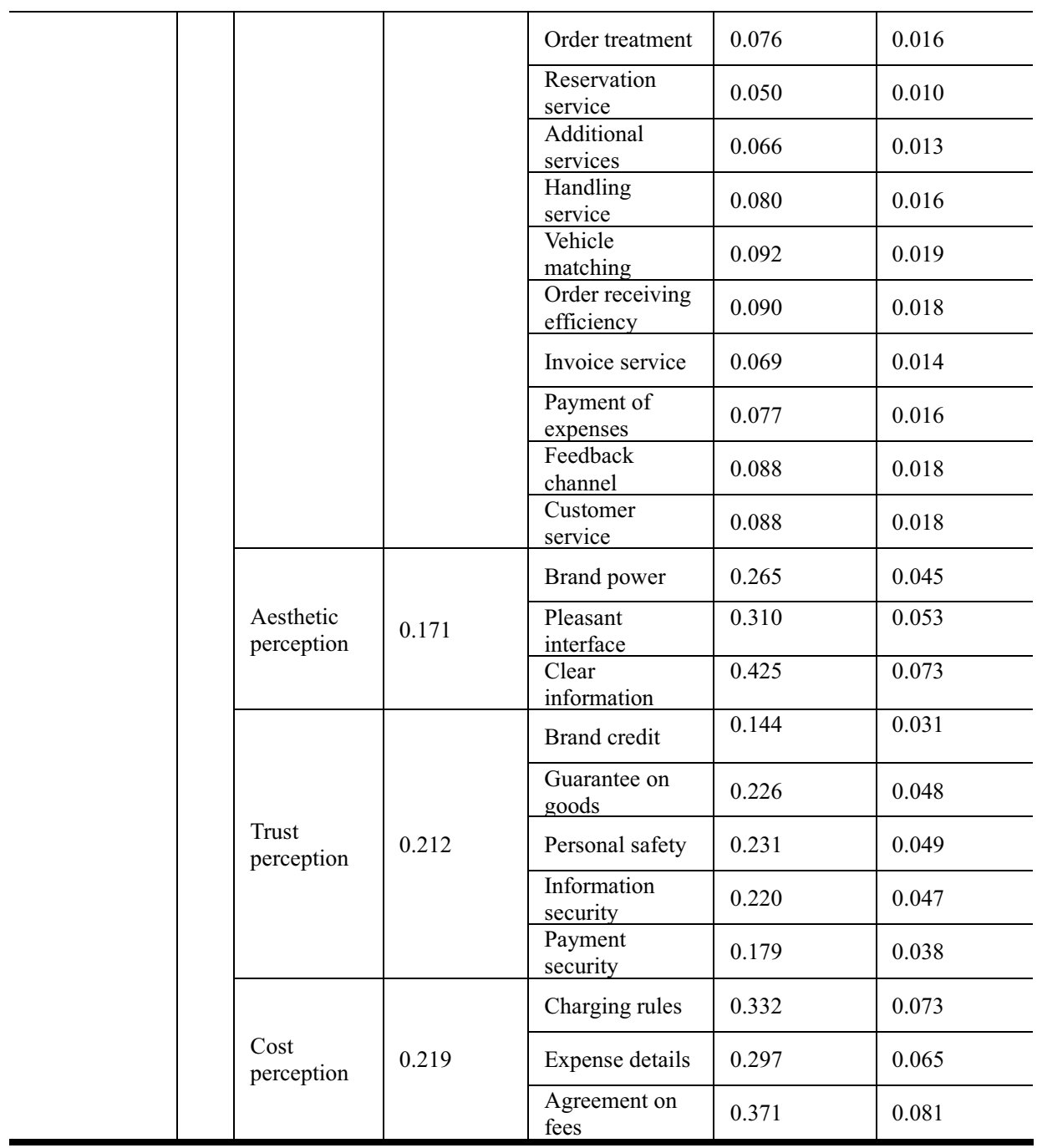

\subsection{Evaluation of the Validity on User Experience Measurement}

The user experience measurement of intra-city freight Internet products is also employed to DIDI Freight to explore the importance of each dimension to the overall user experience. The experience scores given by 282 users on 26 basic indexes of DIDI Freight v1.0 were collected through questionnaires. On this ground, we could finally determine the experience baselines of DIDI Freight products, offering optimization suggestions according to specific indexes. After the launch of DIDI Freight v2.0, another experience evaluation was carried out in the same way to collect the experience scores from 309 users. Those results were compared with the baseline data to verify the effectiveness of the experience measurement method. By doing so, it can testify to the positive role of index weighting based on grey relation analysis in improving the accuracy of the user experience measurement and leading the future optimization in this regard. 


\subsubsection{Measurement of DIDI Freight v1.0}

A total of 334 questionnaires were collected in the measurement survey of DIDI Freight v1.0, of which 282 were usable, accounting for $84.43 \%$. According to the feedback of research information, this outreach covers a wide range of areas. Among the respondents, $46.45 \%$ were female users, while the remaining $53.55 \%$ were male, basically striking a balance in gender. They were mainly aged from 31 to 50 , accounting for $85.17 \%$ of the total respondents. The user group fits in the characteristics of the user profile of intracity freight Internet products.
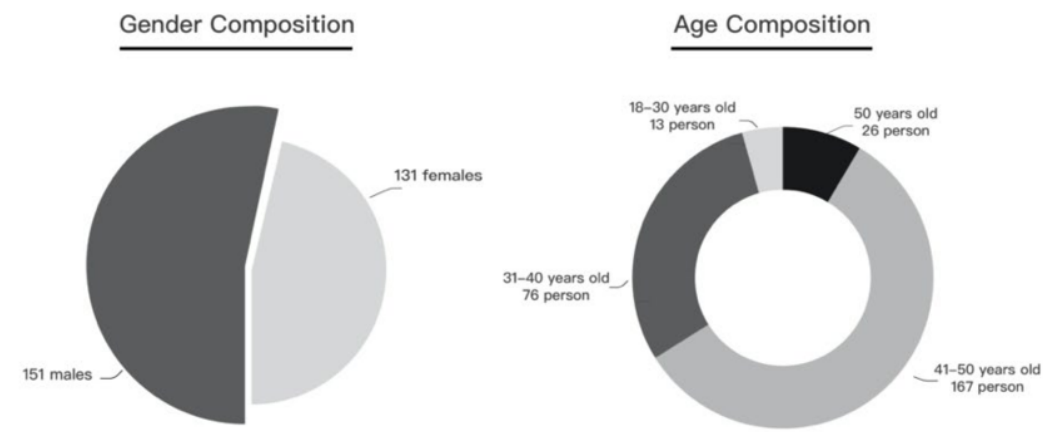

Figure 4. Descriptive statistics of measurement of DIDI Freight v1.0.

Through analysis on the user experience measurement, the results are presented as follows:

Table 8. Experience measurement results of DIDI Freight v1.0.

\begin{tabular}{|c|c|c|c|c|c|c|c|}
\hline \multicolumn{2}{|l|}{ Product Score } & $\begin{array}{l}\text { First-level } \\
\text { index }\end{array}$ & $\begin{array}{l}\text { First-level } \\
\text { weight }\end{array}$ & $\begin{array}{l}\text { Index } \\
\text { score }\end{array}$ & $\begin{array}{l}\text { Second-level } \\
\text { index }\end{array}$ & $\begin{array}{l}\text { Index } \\
\text { score }\end{array}$ & $\begin{array}{l}\text { Second- } \\
\text { level weight }\end{array}$ \\
\hline \multirow{11}{*}{$\begin{array}{l}\text { User } \\
\text { Experience } \\
\text { Measurement } \\
\text { for DIDI } \\
\text { Freight v1.0 }\end{array}$} & \multirow{11}{*}{7.53} & \multirow{2}{*}{$\begin{array}{l}\text { C1 Product } \\
\text { performance }\end{array}$} & \multirow[t]{2}{*}{0.194} & \multirow[t]{2}{*}{1.58} & A1 stability & 8.15 & 0.583 \\
\hline & & & & & A2 Fluency & 8.18 & 0.417 \\
\hline & & & & & $\begin{array}{l}\text { A3 Address } \\
\text { filling }\end{array}$ & 6.75 & 0.072 \\
\hline & & & & & $\begin{array}{l}\text { A4 } \\
\text { Positioning }\end{array}$ & 6.62 & 0.061 \\
\hline & & & & & $\begin{array}{l}\text { A5 Vehicle } \\
\text { type }\end{array}$ & 6.89 & 0.091 \\
\hline & & & & & $\begin{array}{l}\text { A6 Order } \\
\text { treatment }\end{array}$ & 7.43 & 0.076 \\
\hline & & $\begin{array}{l}\text { C2 Product } \\
\text { service }\end{array}$ & 0.204 & 1.36 & $\begin{array}{l}\text { A7 } \\
\text { Reservation }\end{array}$ & 0.00 & 0.050 \\
\hline & & & & & $\begin{array}{l}\text { A8 } \\
\text { Additional }\end{array}$ & 6.84 & 0.066 \\
\hline & & & & & $\begin{array}{l}\text { A9 Handling } \\
\text { service }\end{array}$ & 6.57 & 0.080 \\
\hline & & & & & $\begin{array}{l}\text { A10 Vehicle } \\
\text { matching }\end{array}$ & 6.75 & 0.092 \\
\hline & & & & & $\begin{array}{l}\text { A11 Order } \\
\text { receiving }\end{array}$ & 6.87 & 0.090 \\
\hline
\end{tabular}




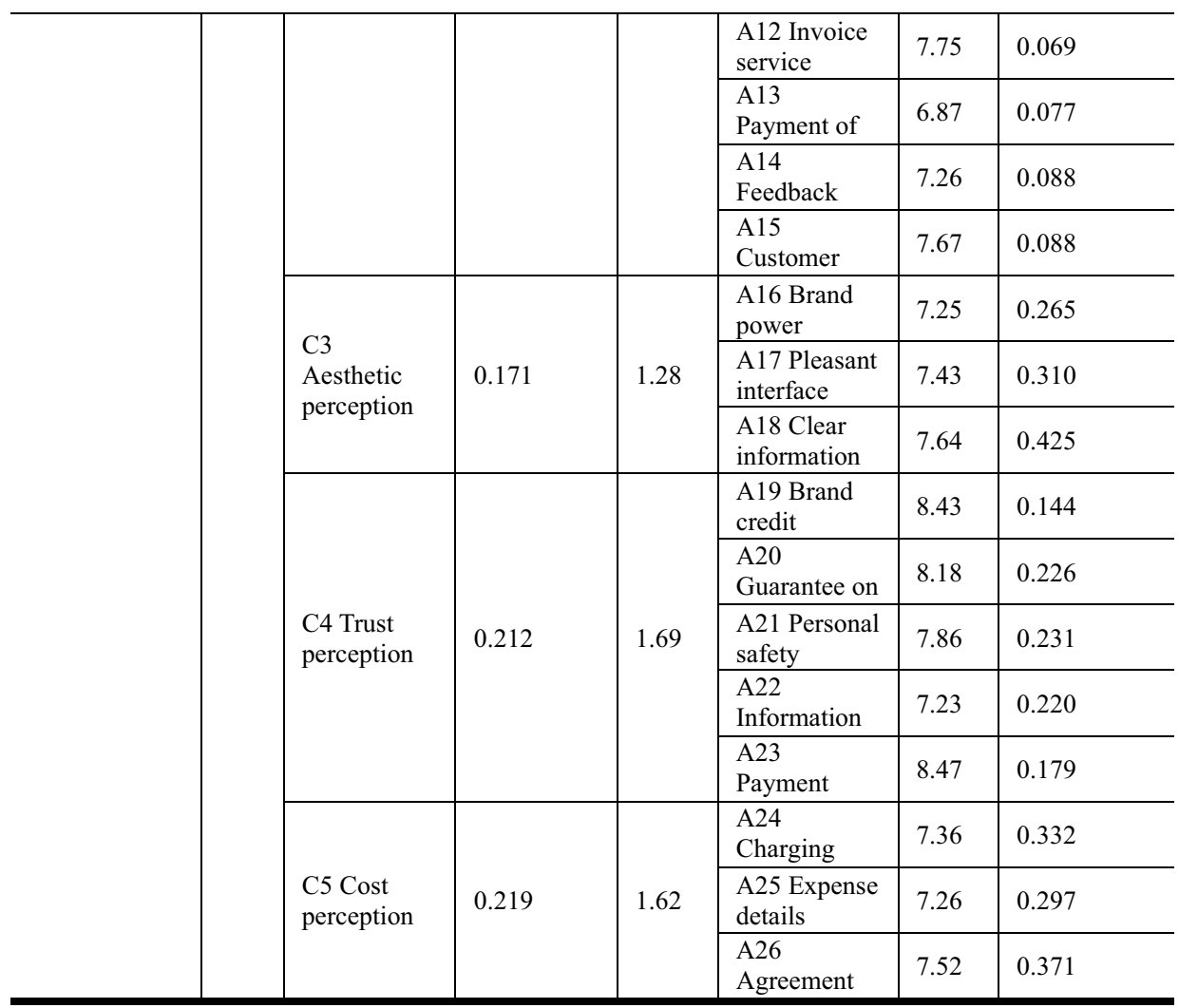

According to the measurement results, we can see the following results (sort in descending order): $\mathrm{C} 4$ trust perception $>\mathrm{C} 5$ cost perception $>\mathrm{C} 1$ product performance $>$ $\mathrm{C} 2$ product service $>\mathrm{C} 3$ aesthetic perception. Among them, C3 aesthetic perception scored the lowest, compared with other indexes. On the one hand, it stems from the least impact of this dimension on the user experience of intra-city freight than those of other indexes, which can be proved from their weights; On the other hand, the DIDI Freight v1.0 is typical of its lightweight, simplicity, and efficiency in terms of experience design, aiming at the functional realization, simple interaction, and consistent experience, hence without too much expense in product interface and scene optimization.

Through in-depth analysis and research on the projects with low scores in the DIDI Freight index, suggestions for the iterative optimization can be obtained in terms of $\mathrm{C} 1$ product performance, $\mathrm{C} 2$ product service, C3 aesthetic perception, $\mathrm{C} 4$ trust perception, and C5 cost perception. Details are shown in Table 9:

Table 9. Suggestions for iterative optimization of DIDI Freight v1.0.

\begin{tabular}{l|l|l|l}
\hline & First-level index & $\begin{array}{l}\text { Second-level } \\
\text { index }\end{array}$ & Recommendations on Iterative optimization \\
\hline 1 & $\begin{array}{l}\text { C1 Product } \\
\text { performance }\end{array}$ & A2 Fluency & $\begin{array}{l}\text { Improve the use fluency for users through the design of } \\
\text { the micro-dynamic effect. }\end{array}$ \\
\hline
\end{tabular}




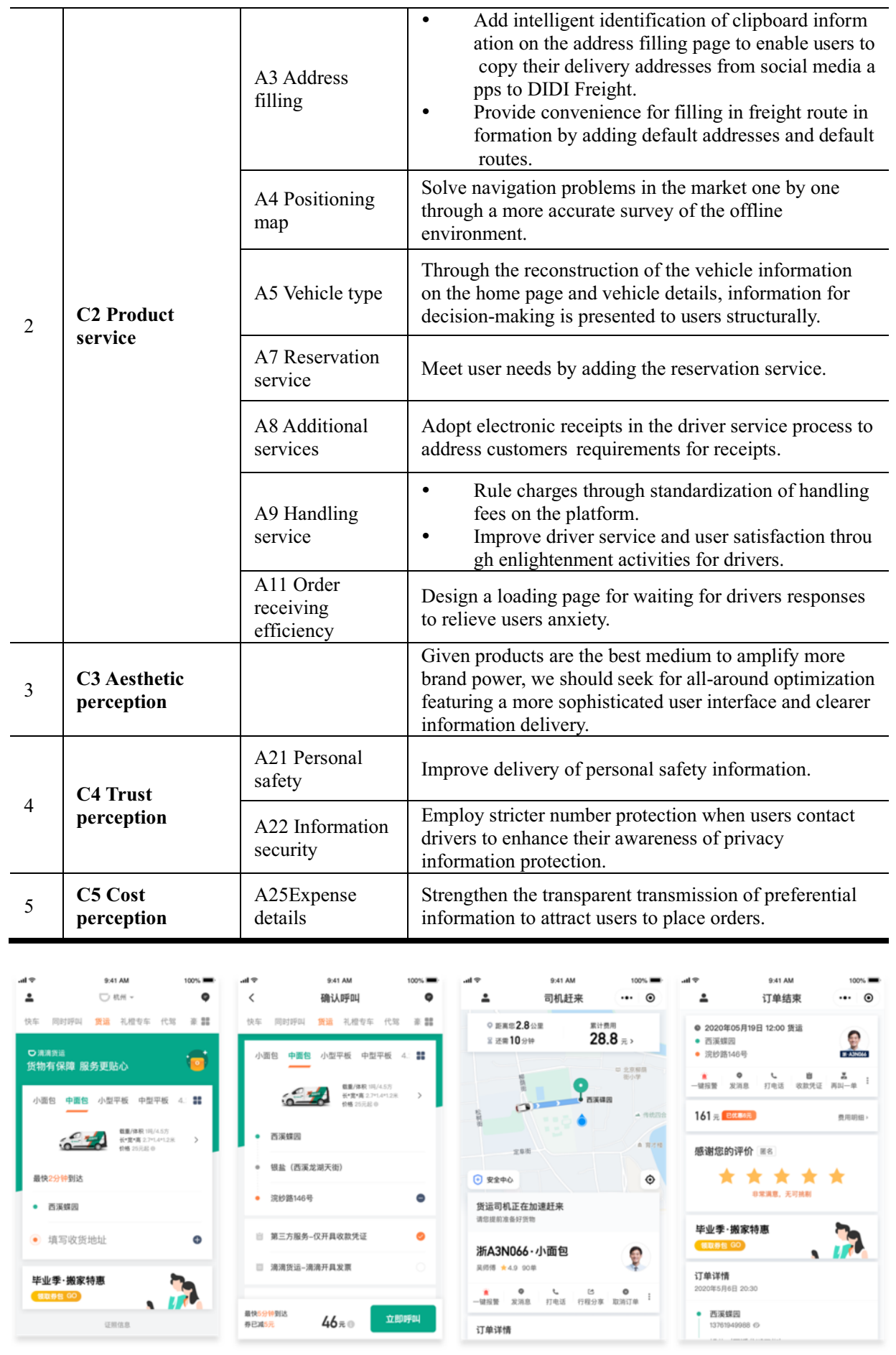

Figure 5. The partial interface of DIDI Freight v1.0. 


\subsubsection{Measurement of DIDI Freight v2.0}

A total of 367 questionnaires were collected in this survey, of which 309 were usable, accounting for $84.20 \%$. According to the feedback of the questionnaires, this outreach covers a wide range of areas. Among the respondents, $44.98 \%$ were female users, while the remaining $55.02 \%$ were male, basically striking a balance in gender. They were mainly aged from 22 to 50 , accounting for $88.67 \%$ of the total respondents (as shown in the figure). The user group fits in the characteristics of the user profile of intra-city freight Internet products.
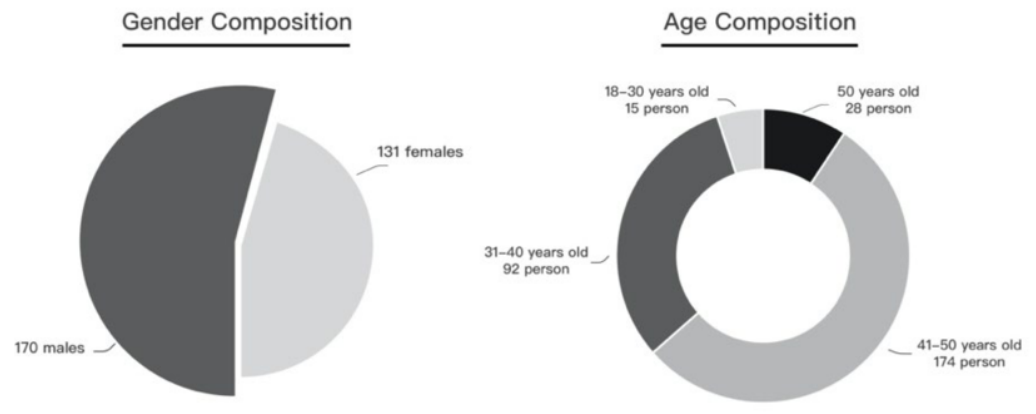

Figure 6. Descriptive statistics of measurement of DIDI Freight v2.0.

Through analysis on the user experience measurement, the results are presented as follows:

Table 10. Experience measurement results of DIDI Freight v2.0.

\begin{tabular}{|c|c|c|c|c|c|c|c|}
\hline \multicolumn{2}{|l|}{$\begin{array}{l}\text { Product } \\
\text { Score }\end{array}$} & $\begin{array}{l}\text { First-level } \\
\text { Index }\end{array}$ & $\begin{array}{l}\text { Index } \\
\text { Score }\end{array}$ & $\begin{array}{l}\text { Contrast } \\
\text { tov1.0 }\end{array}$ & $\begin{array}{l}\text { Second- } \\
\text { level } \\
\text { Index }\end{array}$ & $\begin{array}{l}\text { Index } \\
\text { Score } \\
\text { First- } \\
\text { level }\end{array}$ & $\begin{array}{l}\text { Contrast } \\
\text { to v1.0 }\end{array}$ \\
\hline \multirow{11}{*}{$\begin{array}{l}\text { User } \\
\text { Experience } \\
\text { Measurem } \\
\text {-ent for } \\
\text { DIDI } \\
\text { Freight } \\
\text { v2.0 }\end{array}$} & \multirow{11}{*}{$\begin{array}{l}7.85 \\
(+0.32)\end{array}$} & \multirow{2}{*}{$\begin{array}{l}\text { C1 Product } \\
\text { performance }\end{array}$} & \multirow{2}{*}{1.60} & \multirow{2}{*}{+0.01} & A1 stability & 8.14 & 0.01 \\
\hline & & & & & A2 Fluency & 8.36 & +0.18 \\
\hline & & & & & $\begin{array}{l}\text { A3 Address } \\
\text { filling }\end{array}$ & 7.83 & +1.08 \\
\hline & & & & & $\begin{array}{l}\text { A4 } \\
\text { Positioning }\end{array}$ & 6.61 & -0.01 \\
\hline & & & & & $\begin{array}{l}\text { A5 Vehicle } \\
\text { type }\end{array}$ & 7.76 & +0.87 \\
\hline & & & & & $\begin{array}{l}\text { A6 Order } \\
\text { treatment }\end{array}$ & 7.41 & -0.02 \\
\hline & & $\begin{array}{l}\text { C2 Product } \\
\text { service }\end{array}$ & 1.44 & +0.08 & $\begin{array}{l}\text { A7 } \\
\text { Reservation }\end{array}$ & 0 & 0.00 \\
\hline & & & & & $\begin{array}{l}\text { A8 } \\
\text { Additional }\end{array}$ & 7.67 & +0.83 \\
\hline & & & & & $\begin{array}{l}\text { A9 } \\
\text { Handling }\end{array}$ & 7.43 & +0.86 \\
\hline & & & & & $\begin{array}{l}\text { A10 } \\
\text { Vehicle }\end{array}$ & 7.39 & +0.64 \\
\hline & & & & & $\begin{array}{l}\text { A11 Order } \\
\text { receiving }\end{array}$ & 6.85 & 0.02 \\
\hline
\end{tabular}




\begin{tabular}{|c|c|c|c|c|c|c|c|}
\hline & & & & & $\begin{array}{l}\text { A12 } \\
\text { Invoice }\end{array}$ & 7.58 & +0.01 \\
\hline & & & & & $\begin{array}{l}\text { A13 } \\
\text { Payment of }\end{array}$ & 7.51 & +0.64 \\
\hline & & & & & $\begin{array}{l}\text { A14 } \\
\text { Feedback }\end{array}$ & 7.28 & +0.02 \\
\hline & & & & & $\begin{array}{l}\text { A15 } \\
\text { Customer }\end{array}$ & 7.68 & +0.01 \\
\hline & & & & & $\begin{array}{l}\text { A16 Brand } \\
\text { power }\end{array}$ & 7.77 & +0.52 \\
\hline & & $\begin{array}{l}\text { C3 Aesthetic } \\
\text { perception }\end{array}$ & 1.42 & +0.14 & $\begin{array}{l}\text { A17 } \\
\text { Pleasant }\end{array}$ & 8.40 & +0.97 \\
\hline & & & & & $\begin{array}{l}\text { A18 Clear } \\
\text { information }\end{array}$ & 8.58 & +0.94 \\
\hline & & & & & $\begin{array}{l}\text { A19 Brand } \\
\text { credit }\end{array}$ & 8.53 & +0.10 \\
\hline & & & & & $\begin{array}{l}\text { A20 } \\
\text { Guarantee }\end{array}$ & 8.21 & +0.03 \\
\hline & & $\begin{array}{l}\text { C4 Trust } \\
\text { perception }\end{array}$ & 1.75 & +0.05 & $\begin{array}{l}\text { A21 } \\
\text { Personal }\end{array}$ & 8.18 & +0.32 \\
\hline & & & & & $\begin{array}{l}\text { A22 } \\
\text { Information }\end{array}$ & 7.95 & +0.72 \\
\hline & & & & & $\begin{array}{l}\text { A23 } \\
\text { Payment }\end{array}$ & 8.46 & 0.01 \\
\hline & & & & & $\begin{array}{l}\text { A24 } \\
\text { Charging }\end{array}$ & 7.37 & +0.01 \\
\hline & & $\begin{array}{l}\text { C5 Cost } \\
\text { perception }\end{array}$ & 1.65 & +0.03 & $\begin{array}{l}\text { A25 } \\
\text { Expense }\end{array}$ & 8.13 & +0.87 \\
\hline & & & & & $\begin{array}{l}\text { A26 } \\
\text { Agreement }\end{array}$ & 7.21 & -0.31 \\
\hline
\end{tabular}

According to the measurement results, it can be seen that compared with the previous version, DIDI Freight v2.0 has increased the total experience score by 0.32 , reaching $4.2 \%$. Design changes of DIDI Freight v2.0 mainly happened to the home page and the order confirmation page, standardizing some services and updating the experience link in the whole order process. This practice conforms to the suggestions learned from the measurement of the previous version on iterative optimization, confirming the effectiveness of this measurement method.
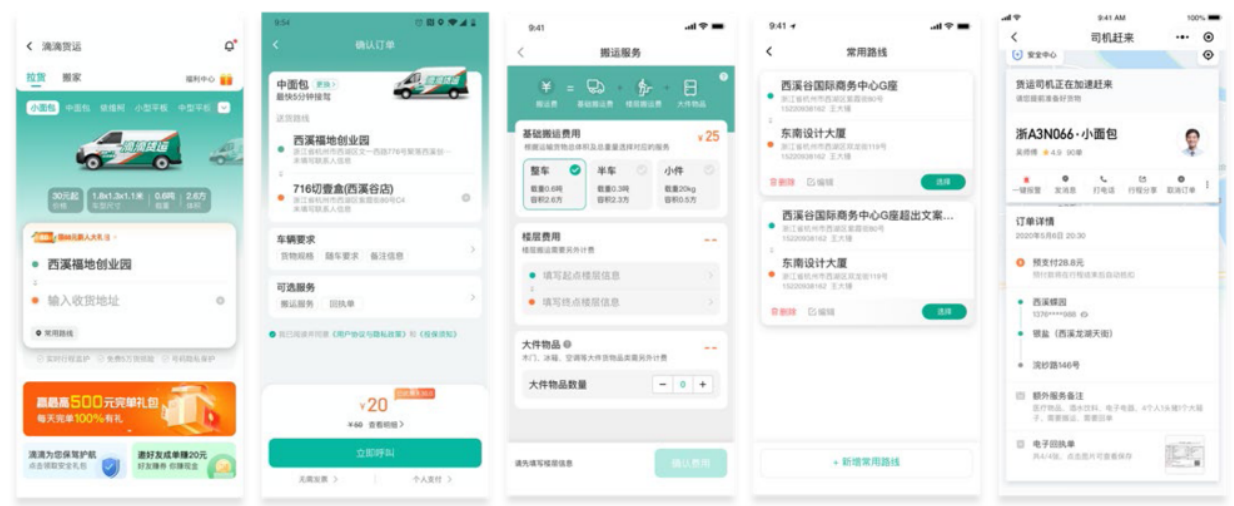

Figure 7. The partial interface of DIDI Freight v2.0. 


\section{Conclusions and future work}

The research on index weighting of user experience is of great significance to the development of Internet products since more accurate user experience measurement can more effectively lead to experience optimization in this regard. By introducing grey relation analysis, this paper proposes a new user experience measurement index weighting method for intra-city freight Internet products. Later, the iteration of two versions of DIDI Freight has employed this method, successfully verifying its effectiveness.

However, due to the limitations to research time, energy, and ability, there are still many aspects to be improved and explored further. (1)Given the small sample size for index weighting of user experience measurement, as well as more friendly attitudes shown by users towards product rating in offline questionnaires, the weighting results may inevitably deviate from the truth, which can be corrected by more sample data and more rigorous guidance in the following study. (2) The study takes DIDI Freight as an example to carry out two versions of user experience evaluation, which then could be extended to other intra-city freight Internet products. In this connection, user experience analysis among competing products becomes available, broadening the comparison diversity.

We're looking forward to more and better methods for the research on user experience index weighting in the future, which have far-reaching significance for enterprises to provide good service and product experience for users and create additional value for their products in the context of the experience-oriented economy and Mobile Internet.

\section{References}

[1] HUANG Wei, LI Zong-ke, HUANG Jian-qiao. Research on Evaluation Index System of APP[J]. Library \& Information Packaging Engineering, 2016(3): 110-117.

[2] Tom Tullis, Bill Albert. Measuring the User Experience: collecting, analyzing, and presenting Usability Metrics (Memorial Edition) [M]. Beijing: Electronic Industry Press, 2020: 6-9.

[3] Wang Zhong, Gao Fang, Wang Xiyang, Fang Hao. Measurement Method of Internet Product User Experience Based on Gray Correlation Analysis [J]. Packaging Engineering, 2018,39(24):141-145.

[4] S.F. Liu,Y.J. Yang. Research Progress in Grey System Research (3004-2014) [J]. Journal of Nanjing University of Aeronautics and Astronautics,2015,47(1):1-18.

[5] Lin, Chong. A review of QoE models and evaluation methods [J]. Journal of Computer Science, 2012, 35(1): 1-15.

[6] Jeff Sauro James R. Lewis: Quantifying the User Experience: Practical Statistics for User Research [M]. Translated by Wenjing Yin, Sha Xu, Chenyan Yang, Xingyuan Sui, and Bozhong Tao, Beijing: Machinery Industry Press, 2012.

[7] Borsci S., Federici S., Bacci S. Asseing User Satisfaction in the Era of User Experience: Comparison of the SUS, UMUX, and UMUX-LITE as a Function of Product Experience[J]. International Journal of Human-Computer Interaction, 2015, 31(8):484-495.

[8] Saariluomaand P., Jokinen J.P. Emotional Dimensions of User Experience: A User Psychological Analysis[J]. International Journal of Human-Computer Interaction, 2014, 30(30):303-320.

[9] Kujala S., Roto V., Väänänen-Vainio-Mattila K., et al. UX Curve: A Method for Evaluating Long-term User Experience[J]. Interacting with Computers, 2011, 23(5):473-483.

[10] Kelly Rodden.,Hilary Hutchinson.,xin Fu. Measuring the User Experience on a Large Scale: UserCentered Metrics for Web Applications[J]. Proceedings of the 28th International Conference on Human Factors in Computing Systems, CHI 2010, Atlanta, Georgia, USA, April 10-15, 2010. 